\title{
Agnieszka Kaczmarek
}

Uniwersytet im. Adama Mickiewicza w Poznaniu

ag.kaczm@amu.edu.pl

\section{CIAŁO, INTYMNOŚĆ I WIECZNOŚĆ. ŚLADAMI JÓZEFA TISCHNERA}

W wydanym po raz pierwszy w 1998 roku Sporze o istnienie człowieka Józef Tischner napisał: „Osoba ludzka staje się podmiotem dramatu jako osoba ucieleśniona. Oznacza to, że nie tylko ona sama, ale również inny ukazuje się w jej ciele i poprzez ciało. Odkrywając obok siebie innego, osoba odkrywa zarazem jego i własną cielesność"1. Dialektyka ludzkiej cielesności ma już swoją długą i bogatą tradycję tak filozoficzną, jak i literacką. Tischner sytuuje ją jednak na płaszczyźnie ludzkiego dramatu, rozdarcia człowieka, braku jednoznacznej relacji zachodzącej tak w nim samym, jak i wobec innych.

Zakres oraz charakter filozoficznych rozważań Józefa Tischnera zdaje się potwierdzać tezę o konieczności zaprowadzenia spójności życia i myśli. Stawiane pytanie oraz propozycje udzielanych odpowiedzi były w refleksji Tischnera usytuowane w kontekście ludzkiej egzystencji, która - co wielokrotnie podkreślał - ma być afirmacją autentyczności. Owa prawdziwość, osadzana przez Tischnera zawsze w kontekście religijności, kapłaństwa i filozofii, najpełniej zrealizowała się $\mathrm{w}$ doświadczeniu cierpienia związanego z chorobą autora Filozofii dramatu. Ta radykalna sytuacja, odzierająca ze wszelkich masek, eksponująca ludzką słabość, jest jednocześnie wkroczeniem na obszar dotychczas chronionej intymności. Zawarta $w$ tytule tekstu kategoria intymności zakłada odsłonięcie człowieka zarówno w wymiarze

${ }^{1}$ J. Tischner, Spór o istnienie człowieka, Kraków 2011, s. 81. 
fizycznym, jak i metafizycznym. Choroba i umieranie spowodowały, że te dwa konteksty szczególnie splotły się w biografii Tischnera, która skonfrontowana została z cierpieniem - fizycznym, jak i duchowym - odsłaniając tym samym wiele płaszczyzn intymności. Kategoria intymności związana jest zawsze $z$ horyzontem świata i doświadczenia - wynika zarówno z przeżyć jednostkowych, konstytuujących ludzką kondycję, jak też z kulturowych ram, które wyznaczają granice pomiędzy tym, co indywidualne, a tym, co uniwersalne. Intymność jest zatem sferą tego, co osobiste i indywidualne, ale jednocześnie skryte i niejawne. To właśnie doświadczenie choroby powoduje, że obszar intymności, tak bardzo osobisty, a nawet zamknięty, może zostać zniesiony. Tak usytuowane ciało wchodzi w nowy obszar dialogu wartości i spotkania, które w perspektywie choroby i umierania radykalnie zmieniają swój charakter.

Materia ciała więzi pragnienia, ograniczając możliwości wolności duszy, tocząc $\mathrm{z}$ nią grę, czy nawet walkę, której nie jest w stanie wygrać żadna ze stron. Poszukując prawdy swojego istnienia, człowiek wikła się w zadaną sobie cielesność. Zadaną - czyli konieczną do spełnienia, realizacji, ale też interpretacji i rozpoznania. To zadanie, zlecone każdemu ludzkiemu istnieniu, zakłada świadomość siebie i ciała - jako pośrednika ze światem, a jednocześnie rzuconego $\mathrm{w}$ ten świat - ciała, które konfrontowane jest $\mathrm{z}$ innymi. Ciało pełne jest pragnień, pożądań, doznań - zarówno przyjemnych, jak i naznaczonych zmęczeniem, znużeniem czy niedyspozycjami. Te z kolei znajdują swoje odbicie $\mathrm{w}$ duchu, będącym $\mathrm{z}$ ciałem nierozerwalnie złączonym, który także uczestniczy w relacji ze światem i z innymi. „Cielesność pisze Tischner - wchodząc w dramat, wchodzi w cały jego horyzont, który jest horyzontem dobra i zła, prawdy i nieprawdy, piękna i nie-piękna. Cielesność jest już z góry ogarnięta tym horyzontem”2 2 .

Kategoria dramatu stanowi jedną z głównych osi refleksji Józefa Tischnera, a jednocześnie jej charakter odbiega od skojarzeń obiegowo funkcjonujących w kulturze. Dramat w ujęciu Tischnera odnosi się do ram egzystencjalnych - wpisuje się w przeżywanie czasu, relację z ludźmi oraz świat, który filozof nazywa sceną. Tak rozumiany dramat zakłada autentyczne bo pozbawione masek - zanurzenie $\mathrm{w}$ świecie oraz relację dialogiczną $\mathrm{z}$ innym człowiekiem. Dramat zakłada zatem relacyjność - osadzoną w czasie ze światem oraz innymi. Intensywność relacji może być zmienna, płynna, niestała, determinowana różnymi doświadczeniami, jednak jest ona nieredukowalnie uświadamiana.

\footnotetext{
2 Ibidem, s. 84.
} 
W tym świetle dramat ciała, według Tischnera, polega na trwaniu w sytuacji nieustannego rozdarcia, usytuowania i nieredukowalnego wyboru pomiędzy tym, co żyje, a tym, co może prowadzić do degradacji. Oto konflikt, w którym osadzone jest ciało - ono "chce być”, realizować siebie, dążyć do znaczenia, które z kolei zakreślone zostaje przez duszę, której - jak wiadomo z tradycji filozoficznej - jest więzieniem. Jednak poprzez czasowość, przemijanie i towarzyszącą mu przemianę ciało zyskuje nową perspektywę. Jest nie tylko bytem samym w sobie, ale jest także dialogiczne - wspiera się obecnością innego. To ono jest gwarantem dialogu - emocji, zabawy, ale także źródłem osamotnienia, które może okazać się radykalnie destruktywne. Dialog i wpisana w niego gra, rozpięta pomiędzy uczestników, łączy się z przyjmowaniem regul, zasad, jednakowo obowiązujących obie strony. Grając, ciało wydobywa z siebie to, czego nie eksponowałoby bez relacji swoje piękno, moc, odpowiedzialność, wierność, które zyskuje też dzięki wolności. Poprzez pracę ciała odnajduje ono wyzwolenie, "przemienienie”, które jest możliwe poprzez wędrówkę (chociażby na górę Karmel, posługując się tu metaforą św. Jana od Krzyża). Ta pielgrzymka - relacja z sobą, jak i z innymi - doprowadza do przekroczenia swojego ciała, a jednocześnie jego afirmacji - jest jego akceptacją oraz negacją. To szansa na wydobywanie dobra, w którym się uczestniczy, a także potwierdzenie istnienia osadzonego w czasie; jest ona jednakże też wystawianiem się na śmierć, która stanowi granicę wieczności. To przez nią odrzuca się mroczny powrót tego samego na rzecz nieskończonego, pod warunkiem że wędrówka nie okaże się błądzeniem. Zagubienie $\mathrm{w}$ drodze do nieskończonego wynikać może z nadmiernej ufności w swoje ludzkie możliwości, afirmację wolności, która jest przecież skończona, a przez to grzeszna, mroczna, osadzona w mgle pozorów.

Intymne dążenie do wieczności kieruje się śladami, znakami potwierdzającymi obecność innego, który był tu „przed”. Nie jest to jednak nieustanne powracanie do przeszłości, do raju utraconego, ale nade wszystko poszukiwanie wiecznej ziemi obiecanej. To ślady tego, kto nas wyprzedził, ale jednocześnie znaki obecności, która nie przemija, a raczej współtowarzyszy, także jako inny, który mobilizuje, a nie zniewala. „Ciało - jak pisze tak istotny dla Tischnera Emmanuel Lévinas - nie jest sposobem popadania podmiotu w niewolę, w zależność od tego, co nim nie jest, ale możliwością posiadania i pracy, dysponowania czasem, przezwyciężania samej inności tego, czym mam żyć. Ciało pozwala właśnie posiadać siebie, dzięki czemu Ja, wyzwolone ze świata poprzez potrzebę, potrafi przezwyciężyć także nędzę tego wyzwolenia"3.

3 E. Lévinas, Całość i nieskończoność. Esej o zewnętrzności, tłum. M. Kowalska, Warszawa 1998, s. 127. 
Wyzwolenie, nazywane przez Lévinasa także "rajskim rozkoszowaniem się", oznacza zawieszenie czasu i wszelkiej troski, czyli tego wszystkiego, co ogranicza, krępuje, skazuje na cierpienie. To ono potwierdza dwoistość ciała, które pragnąc rozkoszy, jednocześnie jest uwikłane w cierpienie - fizyczne, spowodowane chorobą, niedyspozycją. „Być ciałem - pisze Lévinas - to z jednej strony, stać się panem siebie, z drugiej strony - stać na ziemi, być w czymś innym i odczuwać własne ciało jako ciężar" ${ }^{\prime \prime}$. Cierpienie ciała podkreśla, a jednocześnie drastycznie przyjmuje doświadczenie czasu - z jednej strony temporalności, z drugiej natomiast pragnienie nieskończoności. Niedyspozycja ciała odznacza się ograniczeniem jego żywiołowości. Takie doświadczanie jest odmiennym, radykalnie innym uchwyceniem świata. To moment, kiedy ciało pozostaje zniewolone, uczestniczy $\mathrm{w}$ doświadczeniu, które przyszło z zewnątrz, pozostając poza jego wolą i oczekiwaniem. To dramat i rozpacz nad tym, że jest się związanym z bytem.

\section{Skończoność cierpienia}

Doświadczenie cierpienia łączy w sobie dwa wymiary - cielesny i psychiczny. Te skorelowane ze sobą sfery nawzajem na siebie oddziałują, jeszcze silniej akcentując dramatyczność człowieka. W perspektywie myśli i doświadczeń Józefa Tischnera oba horyzonty - tak fizyczny, jak i ten osadzony w sferze refleksji - wpływają na jego postawy przyjmowane wobec świata, a także kształtują nowy obszar myśli, który jest rezultatem egzystencji osadzonej we wnętrzu choroby. Pierwszym obszarem niedomagania i źródłem mentalnych bolączek jest ciało. To ono przysparza elementarnych trudności, które $w$ dalszym stopniu oddziałują na wnętrze. Ciało pozostaje barierą, kokonem, z którego nie można się wydostać. Wymaga ono szczególnego traktowania, stawia opór i oczekuje troski. Tym samym jest fizyczną barierą - w świecie, na scenie dramatu, funkcjonuje zgodnie ze skrajnie odmiennymi niż dotychczasowe zasadami, a jednocześnie jest przeszkodą dla wieczności. Ta dialektyczna natura cierpienia wprowadza jednocześnie na obszar osamotnionej intymności.

Wywołane chorobą cierpienie ciała jest wejściem w nieuchronną skończoność, a jednocześnie - w perspektywie filozofii Tischnera - bramą do nieskończoności. „Nie uszlachetnia” - napisze na karteczce Tischner na etapie już bardzo poważnej choroby, która odebrała mu możliwość mówienia. W eseju z 1999 roku zatytułowanym Mitość autor napisał:

\footnotetext{
${ }^{4}$ Ibidem, s. 190.
} 
Przyznajmy, że są takie prawdy, do których dochodzi się poprzez męczeństwo. Jedną $z$ takich prawd jest prawda, że cierpiąc, cierpimy z Chrystusem. Nie żyjemy dla siebie i nie umieramy dla siebie. Czy żyjemy, czy umieramy - należymy do Boga. Dzięki temu odkryciu możemy mieć udział w boskiej godności cierpienia. Niemniej nie cierpienie jest tutaj ważne. Nie ono dźwiga. Wręcz przeciwnie, cierpienie zawsze niszczy. Tym, co dźwiga, podnosi i wznosi ku górze, jest miłośćs.

Cierpieniu zatem można się poddać, można je również przezwyciężać, konfrontować się z nim. Ta relacja polega na nadaniu cierpieniu znaczenia, zwłaszcza poprzez doświadczenie miłości tak swojej, jak i innego. Przyjęcie cierpienia i zaakceptowanie faktu, że to ono ostatecznie decyduje o losie człowieka - niszczy. Tak traci się nadzieję, gdyż człowiek uwiadamia sobie, że traci siebie. To jednak miłość dźwiga beznadzieję cierpienia, odkrywając przed cierpiącym to, co w nim, jako osobie, jest trwałe i niezniszczalne. Odpowiedź na cierpienie decyduje o wartości nadanej temu doświadczeniu. Za każdym razem jest to sytuacja intymna, jednostkowa i niewyrażalna. Człowiek swoje cierpienie, przychodzące z zewnątrz, przetwarza wewnątrz siebie. Wojciech Bonowicz przywołuje następujące wyznanie Tischnera: „Uświadamiam sobie, że z powodu choroby nie wrócę do wielu rzeczy. I mi tego, cholera, nie żal! [...]. Zamiast tego, żeby mi choroba zubożyła świat, to mi go wzbogaciła. Dała mi poczucie wolności. Uświadomiła mi też zewnętrzność ciała"6.

Tischner nie racjonalizuje cierpienia, raczej dotyka go jako śladu intymności, tajemnicy, sytuując je w perspektywie miłosierdzia, dzięki któremu może ono zostać przezwyciężone. Cierpienie sprawia, że człowiek staje się inny, obcy, nietożsamy z życiem, obcy również dla siebie. Dla Tischnera tą figurą inności, która paradoksalnie nie pojawia się zbyt często $\mathrm{w}$ jego tekstach, jest Hiob, którego w Sporze o istnienie człowieka nazywa „innym dla innych". Doświadczenie choroby i towarzyszące jej cierpienie oddala od świata, rodzi nieco zaciekawienia, lecz nie zaprasza do zbliżenia. Cierpienie zatem jest czymś monadycznym, zamkniętym i niepodzielnym, a jednocześnie wyjątkowym i autentycznym. Nie można go zrelatywizować, rozdzielić, pozostaje jedynie bezradność w jego monolitycznej całości i niezrozumieniu, które także było samotnym doświadczeniem Hioba: „Nie ma już przyjaciól, nie ma bliźnich, są tylko coraz bardziej inni. Inność rozrasta się i rozpycha, niszczy wszelkie podejrzenie o podobieństwo, wszelkie «dzięki innemu», a nawet «poprzez innego»"7. Powracając do postaci Hioba wiele

${ }^{5}$ J. Tischner, Miłość, cyt. za: T. Ponikło, Józef Tischner - myślenie wedtug miłości. Ostatnie słowa, Kraków 2014, s. 259.

${ }^{6}$ W. Bonowicz, Tischner, Kraków 2001, s. 470.

7 J. Tischner, Spór o istnienie czlowieka, op. cit., s. 262. 
lat później, Tischner położy akcent na nadzieję i ufność obecne u cierpiącego. Odrzuci samouwielbienie cierpienia, rozkochanie się $\mathrm{w}$ cierpieniu, na rzecz wierności, nawet jeśli jest ona bezgranicznie osamotniona. Z kolei Władysław Stróżewski pisze:

Bieda, nędza, grzech, zło nie mogą stać się "same w sobie” przedmiotami miłości. Miłość jednak na nich się nie zatrzymuje. Idzie i szuka głębiej. Dostrzega, że istnieje podmiot tych przejawów zła, że istnieje człowiek, który jest transcendentny wobec nich, mimo że one go dotknęły albo że im uległ. W polu widzenia pojawia się kontrast między tym, co jest, a tym, co być powinno. Rodzi się ból i żal, że stało się nie to, co być powinno, lecz zło, którego powinno nie być8 8

\section{Samotność śmierci}

Dokładnie pięćdziesiąt lat temu, w 1966 roku, 35-letni wówczas Józef Tischner wygłaszał rekolekcje wielkopostne w poznańskim kościele dominikanów - już wówczas obecne były w myśli księdza Tischnera intuicje, które odnowi on w sytuacji swojego własnego doświadczenia cierpienia, choroby i umierania.

Tischner zadaje pytanie o potrzebę cierpienia, o jego znaczenie w ludzkim życiu. Odpowiadając na nie, mówi o autentyczności. Cierpienie jest tą sytuacją, kiedy człowiek naprawdę jest sobą, schodzi ze sceny, na której grał szereg ról, zdejmuje maskę, która dotychczas ukrywała jego prawdziwe oblicze. To moment, kiedy wypowiada się swoje imię, do tej pory ukrywane pod pseudonimem życiowych ról. Odchodzi się od gry na rzecz afirmacji autentyczności. Dopiero w sytuacji tego granicznego doświadczenia ujawnia się prawdziwe "ja”, które do tej pory było starannie maskowane. To odkrywanie, a jednocześnie zdobywanie samego siebie: „Taki jest głęboki sens tego wchodzenia $\mathrm{w}$ cierpienie. Ono nie jest, jakby się pozornie wydawało, absurdalne, bo ono nas po raz ostatni stawia na nogi. Złudzenia muszą pozostać tutaj" ${ }^{\prime}$. Archetypem wejścia $\mathrm{w}$ doświadczenie cudzego cierpienia pozostaje miłosierny Samarytanin - przekraczając czysto ludzkie ograniczenia, które nakazywałyby w jego sytuacji opuścić i w obojętności przejść obok obcego człowieka, pochyla się on nad nim, realizując ewangeliczne miłosierdzie. Postawa Samarytanina stała się ideałem posługi i postępowania wobec chorego i cierpiącego. Władysław Stróżewski, odwołując się do kategorii miłosierdzia, pisze:

8 W. Stróżewski, W strone filozofii miłosierdzia, „Znak” 2003, nr 574, s. 18-19.

${ }^{9}$ J. Tischner, Naprawić ludzka śmierć, „Tygodnik Powszechny”, 23 marca 2008 r., s. 10. 
Ewangeliczny Samarytanin nie stałby się archetypem człowieka miłosiernego, gdyby jedynie zapłakał nad obrabowanym i poranionym bliźnim i przekazał mu wyrazy współczucia: miłosierdzie urzeczywistniło się wtedy, gdy obmył mu rany i zawiózł do gospody, by zaoferować mu opiekę ${ }^{10}$.

Miłosierdzie jest zatem zawsze zanurzone działaniu, doświadczeniu i zaakceptowaniu inności, która może prowadzić do radykalnego przekraczania dotychczasowych egzystencjalnych i emocjonalnych ograniczeń, a jednocześnie skonfrontować nas z perspektywą wieczności, wprowadzaną przez śmierć.

Takie rozumienie cierpienia inicjuje dyskusję nad śmiercią, która zawsze jest obecna jako śmierć innego człowieka. To ona jest zatrzymaniem przyszłości, ale jednocześnie otwarciem na nieskończoność. Separacja, jaką jest śmierć, zawsze jest radykalna; uświadamia, że każdy byt ma swój czas i swoją wewnętrzność. Lévinas pisze:

Nieprzewidywalność śmierci polega na tym, że nie mieści się ona w żadnym horyzoncie. W żaden sposób nie można jej ująć. Śmierć zagarnia mnie, nie dając mi szansy, jaką daje walka, albowiem we wzajemnej walce mogę chwycić tego, kto mnie chwyta. Śmiertelność naraża mnie na przemoc absolutną, na zabójstwo pod osłoną nocy $^{11}$.

Godziny śmierci nikt nie wyznaczył, a jednocześnie pozostaje ona momentem wiecznego przeznaczenia. Jest doświadczeniem międzyosobowym, a jednocześnie skrajnie samotnym i niepodzielnym, do którego zbliża się w strachu, ale i z nadzieją. Jest tajemnicą, którą bierze się na siebie, od której dzieli tylko czas, płynący wbrew człowiekowi, pod prąd.

Przekonanie, że kiedyś się przeminie, jest skandalem. Ta myśl zdaje się kwestionować każde przeżycie, własne doświadczenie, a nawet przeczyć mu. Biskup Hippony pisał:

Okazuje się, że czas nie biegnie bezużytecznie Ani nie zostawia naszych uczuć w zupełnym bezruchu. Dokonuje dziwnych rzeczy w ludzkim umyśle. Świtał oto i mijał nade mną dzień za dniem. Ten przepływający czas przynosił mi nowe obrazy i nowy pokarm dla pamięci ${ }^{12}$.

Świadectwo doświadczenia czasu, a wraz z tym przemiany, zdaje się więc wewnętrznie sprzeczne. Intuicje $\mathrm{z}$ nim związane wydają się trudne do pogodzenia ze sobą: nasze doświadczenie jednocześnie dowodzi rzeczywi-

\footnotetext{
${ }^{10}$ W. Stróżewski, op. cit., s. 20.

11 E. Lévinas, op. cit., s. 280.

12 Św. Augustyn, Wyznania, tłum. Z. Kubiak, Kraków 1997, s. 96.
} 
stości przemijania, realności czasu, i jej przeczy. Od procesu przemijania, a wraz z tym perspektywy wieczności, nie ma ucieczki - to także przesłanie chrześcijaństwa, tak odmienne od perspektywy klasycznej starożytności. Śmierć radykalnie zmienia perspektywę wobec tymczasowości życia, a jednocześnie stanowi transgresję umożliwiającą wkroczenie na obszar nieskończoności. Dla chrześcijaństwa taki charakter mają dwie przestrzenie - przestrzeń rajska oraz piekielna przestrzeń wiecznego potępienia. Tylko w kontekście tych dwóch płaszczyzn zaświatów można mówić o wieczności, w opozycji do czyśćca, który jest miejscem tymczasowego, implikowanego nadzieją, oczyszczenia. Tej nadziei nie daje chociażby piekło, co w swoim poemacie wyeksponował Dante:

Przeze mnie droga w miasto utrapienia,

Przeze mnie droga $w$ wiekuiste męki,

Przeze mnie droga w naród zatracenia.

Jam dzieło wielkiej, sprawiedliwej ręki.

Wzniosła mię z gruntu Potęga wszechwłodna,

Mądrość najwyższa, Miłość pierworodna;

Starsze ode mnie twory nie istnieją,

Chyba wieczyste - a jam niepożyta!

Ty, który wchodzisz, żegnaj się z nadzieją...13

Według Tischnera, to właśnie poprzez mijający czas ujawnia się ludzka śmierć - przemijalność, zmiana i zapadanie w przeszłość. Minione nie wraca, zabierając część bytu. Wybieranie pomiędzy jedną a drugą możliwością jednocześnie zadaje śmierć temu, czemu nie będzie dane się ziścić. Porzucanie daje przedsmak radykalnej utraty, porzucenia wszystkiego, a wraz z tym wejścia w nieredukowalną i największą samotność. To sytuacja największego ogołocenia i separacji, która wraz z przybliżająca się ostatnią godziną jeszcze bardziej nabrzmiewa. Tischner posługuje się tu metaforą pomocnych rąk - przyjaciół, rodziny, bliskich - które nagle się kończą. To samotność bólu, bólu fatalnego, nieodwracalnego i ostatecznego. Śmierć owiana i pełna trwogi - z powodu nieznajomości i niemożności ucieczki - jest jednocześnie daleka od troski, którą mogłaby ostateczność wyeliminować. Śmierć przychodzi zawsze z zewnątrz, jest nieoswojona i niepokonalna, a jednocześnie obecna, mimo pojawiającego się bólu i buntu.

Najpełniejszą filozoficzną wykładnią śmierci jest tekst Józefa Tischnera Prolegomena chrześsijańskiej filozofii śmierci ${ }^{14}$. Uwzględniając refleksję Heideggera, Tischner akcentuje przede wszystkim ogołocenie przez śmierć - do-

${ }^{13}$ D. Alghieri, Boska komedia, tłum. E. Porębowicz, Wrocław 1986, s. 16.

${ }^{14}$ J. Tischner, Świat ludzkiej nadziei, Kraków 2014, s. 303-332. 
świadczenie transcendentne, niosące spustoszenie. Niesie ono ze sobą rozpacz, tak ściśle powiązaną z trwogą - niemal zmysłową, podstawową, pierwotną. Odpowiedzią człowieka na rozpacz pozostaje nadzieja, która niesie ze sobą zgodę na samego siebie, a wraz z tym ostateczne doświadczenie. To pustoszenie, przychodzące $\mathrm{z}$ zewnątrz, wywołuje radykalne sytuacje wytwarzania oraz niszczenia. Tak samo Tischner charakteryzuje śmierć Jezusa:

Jezus odczuwa śmierć jako wartość ambiwalentną, pozytywną i negatywną zarazem. Śmierć jest dla Niego wartością pozytywną, ponieważ jest pomostem do osiągnięcia jakiegoś w sobie wartościowego życia. Że zaś jest pomostem koniecznym, nosi tę wartość sama w sobie. Natomiast śmierć jako umieranie jest wartością negatywną. Gdy Jezus zostaje nią dotknięty bezpośrednio, gdy zbledną w Jego świadomości obrazy życia, a rozpętają się bóle konania, powie: „Niechaj odejdzie ten kielich..." Ale zaraz potem, gdy znowu obrazy życia staną się żywe, pójdzie naprzeciw oprawcom z poczuciem nienaruszonej godności własnej, która trwać w Nim będzie aż do końca procesu i dalej15.

Rozważania Tischnera podkreślają niezbywalną konieczność śmierci Jezusa i jej znaczenie dla całego chrześcijaństwa. To, co kryje ludzka śmierć, jest poddane tej jednej śmierci, która jest gwarantem wieczności dla człowieka. Oto dwojaka natura śmierci Chrystusa - śmierci człowieczeństwa i jej konieczności, a jednocześnie śmierci, która tym samym zostaje przezwyciężona, a przez to zniesione zostają płynące $\mathrm{z}$ niej ograniczenia. Ta kontestacja, poróżnienie ze śmiercią, sprzeciw wobec umierania, wprowadza doświadczenie nieskończoności. Tak przeistoczona śmierć, wprowadzając w obszar nieskończoności, udowadnia, że doświadczenie to nie jest końcem, nie jest absurdalne.

\section{Wieczność miłosierdzia}

Śmierć nie jest bowiem przeszkodą dla ducha - stanowi barierę, która jednak przemija, otwierając nas na nieograniczone. Jak pisze Lévinas: "Żyjące w człowieku marzenie o szczęśliwej wieczności, a nie tylko o doraźnym szczęściu, nie jest zwykłym szaleństwem. [...] Czas dokonuje się nie w śmierci, lecz w czasie mesjanistycznym, który nieustanność przekształca w wieczność" 16 . Wieczność i jej płomień - ten, który oczyszcza, przynosząc to, co nowe - realizuje się $\mathrm{w}$ miłosierdziu, które stało się jednym $\mathrm{z}$ ostatnich zagadnień podjętych przez Józefa Tischnera w końcowych miesiącach jego

\footnotetext{
${ }^{15}$ Ibidem, s. 327.

${ }^{16}$ E. Lévinas, op. cit., s. 344.
} 
życia. Dla umierającego księdza - podobnie jak swego czasu dla św. Faustyny - był to zwrot niemal rewolucyjny. Cierpiący na chorobę nowotworową Tischner poszukuje pomostu współcierpienia. Znajduje go w osobie łagiewnickiej świętej. Rodzi się wspólnota współodczuwania, ofiarowanie bólu, który poprzez oddanie - przestaje być wyłącznie własnym, a staje się współdzielony z innym. Skoro cierpienie nie uszlachetnia cierpiącego, to może stać się depozytariuszem miłości, która uszczęśliwia. Tischner pisze:

Wiara siostry Faustyny nie jest wiarą „źle uszczęśliwionych" - tych, którzy swym nieszczęściem "kokietują Boga”. Jest religią szczęśliwych, którzy dzięki współodczuwaniu z Chrystusem potrafią odkryć sens cierpienia i dojrzewać w cierpieniu17.

Komentarze Tischnera do Dziennika Faustyny uznać można za szczególny przypadek kroniki własnego umierania, porządkowania myśli, ponownego godzenia się z dawnymi dyskutantami (Nietzschem, Robespierrem), doświadczeniami (rewolucjami, komunizmem), ale także otwieraniem się na nowe mistyczne autorytety. Temat miłosierdzia stał się najważniejszym problemem, a jednocześnie najintymniejszym doświadczeniem $\mathrm{w}$ ostatnich miesiącach choroby. Obrazek Jezusa Miłosiernego towarzyszył Filozofowi do końca - był świadkiem jego umierania, kiedy bezradne ciało przestawało być jego ciałem, a także świadkiem jego śmierci oraz ostatecznego otwarcia na wieczność. Droga choroby była dla Tischnera drogą do otwarcia tak na wieczność, jak i na miłosierdzie. To wieczność, która podważa cały dotychczasowy czas, stawia go pod znakiem zapytania, pyta o niego i w ten sposób skupia wszystko: ciało, cierpienie, myśl, umieranie, aż $\mathrm{w}$ końcu śmierć. Wieczność zbiera w jedno cały czas, który był, i otwiera go na radykalne inne. Każde z wymienionych doświadczeń zawsze powinno być osadzone w realiach miłosierdzia. Czas ludzki, poprzedzający wieczność, składa się z chwil wypełnionych działaniem i doświadczeniem, które może być inkrustowane złem, cierpieniem, chorobą, niedyspozycją, stającymi się tymi częściami życia, nad którymi nie ma możliwości panowania. W refleksji Tischnera, odwołującego się do postaci biblijnego Hioba czy bolesnych przeżyć siostry Faustyny, zawsze wynikają one z dotknięcia Boga. Pomimo religijnego kontekstu swej myśli, Tischner nie waha się jednak wejść w dyskusję nad problemem miłosierdzia. Partnerem w tej rozmowie jest Fryderyk Nietzsche, który w miłosierdziu widzi przede wszystkim słabość. Mechanizm resentymentu, zdaniem Nietzschego, sprawia, iż bezradność, małość jest dla chrześcijanina siłą pozwalającą osiągnąć więcej. Tischner jednak horyzont miłosierdzia postrzega zupełnie inaczej: miłosierdzie jest doświadczeniem

${ }^{17}$ J. Tischner, Drogi i bezdroża miłosierdzia, Kraków 2015, s. 83. 
„współ-odczuwania”, czyli sposobem poznania cudzej kondycji, cierpienia, słabości. To jeden $\mathrm{z}$ warunków uczestnictwa w świecie, dramacie, który nie kończy się na osamotnionym trwaniu.

Rozpoznanie, współodczuwanie jest sprawdzianem miłosierdzia, wezwaniem drogi, która ku niemu może prowadzić lub - używając sformułowania autora Filozofii dramatu - sprowadzać na manowce. Zawsze jest to jednak nieograniczona wolność, która stoi u bram wieczności, otwierając przed człowiekiem możliwość zmiany i podważenia dotychczasowych reguł. Dlatego też myślenie w perspektywie miłosierdzia Tischner nazywa rewolucyjnym, kwestionującym postawę ograniczającą się do współczucia na rzecz "przeniesienia się $\mathrm{w}$ sytuację cierpiącego"18. Tym samym stawia człowieka w nowym świetle doświadczenia umierania i śmierci - nie jest już ona jedynie nieuniknionym opustoszeniem, które wypełnia trwoga i bezsilność. Ta pełna ludzkiej rozpaczy sytuacja staje się możliwością zanurzenia się w wieczność i totalność nieskończoności. Miłosierdzie, jak się okazuje, może zakwestionować ostateczność śmierci. Tischner, podejmując ten problem $\mathrm{w}$ horyzoncie egzystencjalnym, przekonuje, że $\mathrm{w}$ obrębie tych ram śmierć nie oznacza końca, lecz nowy początek.

\section{The Body, the Intimacy, and the Eternity - Following the Path of Józef Tischner}

\section{Summary}

The main problem of this article is Józef Tischner's thought about the disease, death and mercy. The experience of the disease, which are also experienced Tischner - makes the area of intimacy, so very personal and even closed can be reduced. So arranged the body enters a new area of dialogue - values and meetings, which in the long illness and death radically change their character. Disease and related existential experience made a special return in thought Tischner directing them to the mercy of the problem and resuming the problem of death situated in the context of eternity.

Słowa kluczowe: miłosierdzie, cierpienie, wieczność, śmierć

Keywords: mercy, suffering, eternity, death

DOI: $10.14746 /$ cbes.2016.15.5

18 Ibidem, s. 54. 